\title{
Understandings of Character and Virtue Education in Riga: Main Findings
}

\author{
Svetlana Surikova ${ }^{1}$ Dr.paed.; Tamara Pigozne ${ }^{2}$ Dr.paed. \\ Manuel Joaquin Fernández-González ${ }^{3}$ Dr.paed.; Ieva Stokenberga ${ }^{4}$ Dr. psych. \\ University of Latvia, Latvia \\ svetlana.surikova@lu.lv¹; tamara.pigozne@lu.lv² \\ manuels.fernandezs@lu.lv ${ }^{3}$; ieva.stokenberga@lu.lv ${ }^{4}$
}

\begin{abstract}
During the last decade, moral education issues are widely discussed in Latvia and worldwide by practitioners, researchers and policy makers. Different understandings of character and virtue education are present in this debate, and this could blur the quality of communication between school leaders, teachers and parents in this relevant aspect of pupils' education. The aim of this study was to investigate the diverse understandings of character and virtue education in Riga city, the capital of Latvia. For answering this question, an online mixed-method survey was conducted from March to May 2018 involving 759 respondents (school pupils and their parents, pre-service and in-service teachers, school leading staff and educational authorities). The results showed that in Latvia prevails the belief that character education and virtue education have different goals, even if they are interrelated, whereas the main stream in international virtue ethics literature is to consider them as equivalents. The possible explanations of this discordance are discussed and some recommendations for reaching a unified understanding of character and virtue education in Latvian educational system are put forward.
\end{abstract}

Keywords: character education, school education, understandings, virtue education, virtue ethics.

\section{Introduction}

During the last decade, moral (character, virtue) education issues are being widely discussed in Latvia (Saeima approves lessons..., 2015; Morality guidelines workgroup..., 2015; 'Courage' and 'Moderation'..., 2016; Krolis, 2017; Fernández-González, 2019a; 2019b) and worldwide (Kristjánsson, 2013; What is Character..., 2019; Berkowitz, Bier, 2006; Harrison, Morris, Ryan, 2016; The Jubilee Centre..., 2017; The National Society, 2017) at the level of practitioners, researchers and policy makers.

Recently, the contents of character and virtue education at school have been under intensive discussion in Latvia, leading in 2016 to the adoption of the Cabinet of Ministers' regulation No 480 "Guidelines for the upbringing of learners and the procedure for evaluating information, teaching aids, materials and teaching/learning and upbringing methods" (Izglītojamo audzināšanas vadlīnijas..., 2016). The process started in 2015, when the Latvian parliament (Saeima) approved the amendments to the Education Law intended to provide moral education at school in line with the values of the Constitution, and a workgroup led by the National Centre for Education of the Republic of Latvia for preparing the guidelines approved in 2016 (Morality guidelines workgroup..., 2015; 'Courage' and 'Moderation'..., 2016). The guidelines include twelve virtues to be developed by pupils at school as the manifestation of their personal free thinking and behaviour, namely: responsibility, studiousness, courage, honesty, wisdom, kindness, compassion, moderation, self-control, solidarity, justice, tolerance. Those virtues are intended to facilitate the practice of a number of values considered to be of particular importance: life, respect, freedom, family, marriage, work, nature, culture, Latvian language and Latvian State.

One of the main streams in the international scientific literature on virtue ethics is to consider that character education and virtue education are two faces of the same coin, because character education is about facilitating the acquisition of virtues. For example, according to K. Kristjánsson, the terms 'character education' and 'virtue education' are interchangeable and are understood as any form of moral education that foregrounds the role of virtuous character in the good life (Kristjánsson, 2013, 271-272). Similarly, character education is supposed to refer to any implicit or explicit educational activity that helps people to develop character qualities or virtues (Harrison, Morris, Ryan, 2016, 18); to develop positive personal strengths called virtues (The Jubilee Centre..., 2017, 2); to develop a good character, i.e., knowing, caring about, and acting upon core ethical values (Berkowitz, 2008); and to develop and celebrate the flourishing of people through the cultivation of an expansive range of moral, spiritual, intellectual, civic and performance character virtues (The National Society, 
2017,6). The tenants of this approach argue that the presence of moral virtue differentiates a character strength from a traditional personality trait (McCullough, Snyder, 2000; Park, Peterson, Seligman, 2004).

It should be acknowledged that some scholars, in particular from the field of psychology, do not always recognize the necessity of speaking about virtues when addressing character education. Instead of linking character strengths to morality and virtue, they prefer to associate it with prosocial phenomena or to dispositional qualities that enable or promote well-being (Goodman, Disabato, Kashdan, 2019). However, some of the main representatives of positive psychology have acknowledged the necessity of addressing the moral dimension of character and the convenience of using the language of virtues (Peterson, Seligman, 2004).

In Latvia, the understanding of these terms is not univocal. As mentioned above, the Guidelines (Izglitojamo audzināšanas vadlīnijas..., 2016) used largely the words 'virtue' and 'value' (respectively, 20 times and 14 times, including their derivations), but the word 'character' is used only once in the document, in the expression 'strict character', as a component of the virtue of courage. And in the public discussion it seems to be a very diverse understanding of the terms related to moral education, such as values, virtues, and character. Certainly, those terms can be understood in different ways: there are different approaches to explaining them, and there is not a "right" or "wrong" understanding. However, it seems important to agree on a concrete understanding of these concepts in the Latvian education system. A common language of virtues and values would facilitate the communication between school leaders, teachers and parents, so that they can all work as a team for the best interest of children (Fernández González, 2019c, 16). Otherwise, misunderstanding in this field could hinder the peaceful and meaningful implementation of character and virtue education at school.

The aim of this study was to investigate the diverse understandings of character and virtue education in Riga city, the capital of Latvia. In June 2018, the primary descriptive quantitative findings of the research were summarized in a needs analysis report (Surikova, Pigozne, 2018), which was elaborated for the purposes of the Erasmus+ project "Supporting teachers for developing intra-personal competencies and character education at school - Arete Catalyst" (2017-2019). In this article, the data set was completed and analysed in-depth.

\section{Methodology}

Research questions. The idea behind the research project presented in this paper was to capture in a more scientific way the current understandings of character and virtue education in Riga city in the perspective of the main-stream international understandings. The research questions leading the inquiry were: 1) Do people think that they understand those concepts clearly, or do they feel unclear about them (selfperceived clarity)? 2) Are they regarded as similar or different notions? 3) Are there misunderstandings and myths about character and virtue education in Latvia? We looked also at group differences regarding these questions.

Research tool. An online mixed-method survey was conducted. The questionnaire contained an open question and several closed-ended questions in a Likert scale. The open question was: "Please, share your thoughts: how do you understand the concepts 'character education' and 'virtue education'? Do you see any difference between them? Which ones?" It was the same for all the respondent groups.

The scale questions were organized in three sections. The first section contained five questions: two about respondents' self-perceived clarity in their understanding of the concepts 'character' and 'virtue' (e.g., for me it is clear/not clear what the term 'character' means); and three questions addressing respondents' agreement with statements addressing their understanding of character and virtue education.

The second section was a battery of twice ten identical statements referring first to character education and then to virtue education. Respondents were asked to rate the level of their agreement/disagreement with them, using the same scale. The formulation of the statements of this section was based on the analysis of scientific literature reporting myths and possible misunderstandings of character and virtue education (Kristjánsson, 2013; The Jubilee Centre..., 2017; Fernández-González, 2018). In these two sections, each item was rated in a 7-point Likert scale. Respondents were presented with two antagonistic statements rated respectively 7 and 1 (e.g.: 'character education helps to develop critical thinking' $=7$; and 'character education does not help to develop critical thinking' $=1$ ), and they were asked to position themselves 
between them (e.g., score ' 7 ' = maximum agreement with the first statement; score ' 1 ' = maximum agreement with the opposite - second statement; score ' 4 ' = neutral attitude towards both statements).

The third section of the questionnaire was intended to capture in-service teachers' and school leading staff understanding of character education more in-depth. It contained seven definitions of character education taken from the relevant literature (Kristjánsson, 2013; Krolis, 2017; What is Character..., 2019; Harrison, Morris, Ryan, 2016; The Jubilee Centre..., 2017; Eleven Principles of..., 2010; Character Education..., 2005; Berkowitz, 2008). The chosen definitions of character education had a different focus: some stressed the teaching process, other the involvement of learners, some stressed a formal education, others - the non-formal education settings. This different focus was used for the analysis and interpretations of results of this section. Those two respondent groups rate their agreement/disagreement with them in a 3-point Likert scale. The questionnaire was in Latvian and it was piloted first in paper version and then in the online version before starting data collection.

Sampling and data collection. The population addressed were the main actors of the formal education system: school pupils, pre-service and in-service teachers, parents, school leading staff and educational authorities. The sampling methods were randomized quota sampling. For optimizing the resources available, the data collection was limited to Riga and was organized with the support of the Education, Culture and Sports Department of Riga Municipality within the Erasmus+ project "Arete Catalyst". In spring 2018, the questionnaire was filled by 759 respondents (Table 1). Only the five more representative respondent groups were retained for the analysis.

Table 1

The research sample

\begin{tabular}{|c|c|c|c|}
\hline \multicolumn{2}{|c|}{ Respondent group } & \multirow{2}{*}{$\begin{array}{l}\text { Representative } \\
\text { sample }\end{array}$} & \multirow[t]{2}{*}{ Real sample } \\
\hline Full version & Short version & & \\
\hline School pupils & Pupils & 150 & 226 \\
\hline Pre-service teachers & Students & 150 & 155 \\
\hline In-service teachers & Teachers & 150 & 116 \\
\hline School leading staff & Leaders & 100 & 55 \\
\hline Parents of pupils & Parents & 150 & 191 \\
\hline Educational authorities & Authorities & 20 & 10 \\
\hline \multicolumn{2}{|l|}{ Other } & - & 6 \\
\hline \multicolumn{2}{|l|}{ Total } & 720 & 759 \\
\hline
\end{tabular}

Data processing and analysis. Quantitative data processing and analysis was performed using MS Excel and SPSS 22 software. The distribution of data was checked for normality using Kolmogorov-Smirnov Test. For the comparison between respondent groups regarding section 1 of the questionnaire (selfperceived clarity of understandings and agreement with the given statements), the non-parametric Kruskal-Wallis H Test was used. For comparing the differences between the understandings of 'character education' and 'virtue education' within each respondent group (section 2 of the questionnaire), the nonparametric Wilcoxon Signed-Rank Test was used.

NVivo 11 Plus software was used for analysing the open answers about the understanding of character and virtue education and their eventual differences. In total, 685 expressions were analysed. Each expression was labelled with one of the following categories, which emerged from the data themselves: 'character education and virtue education are the same or similar notions' (concordance with the international understanding of those concepts); 'Character education and virtue education are not the same' (discordance); 'these two notions are interconnected' (partial concordance); and 'self-perceived lack of understanding of those concepts'.

\section{Results}

Regarding the $1^{\text {st }}$ research question (Self-perceived clarity about the concepts 'character' and 'virtue'), in general, respondents' self-perceived clarity about the meaning of the concepts 'character' and 'virtue' was quite high (Table 2, items 1 and 2). The concept 'virtue' was perceived more clearly than concept 'character' $(\mathrm{M}=5.85$ and 5.33, respectively, in a 7-point scale). The analysis of the qualitative data confirmed this finding: overall, only $8.6 \%$ of respondents $(n=60)$ reported a lack of clarity about the notions of character 
education and virtue education. However, the scores were much lower for school leading staff ( $\mathrm{n}=2 ; 3.8 \%$ within group), but slightly higher for students $(\mathrm{n}=27 ; 12.2 \%)$ (Table 3 , item 4$)$.

As regards the $2^{\text {nd }}$ research question (Character and virtue education: similar or different?), a relevant finding of this study was that, overall, respondents believed that 'character' and 'virtue' have quite different meanings $(\mathrm{M}=5.53$, where $7=$ absolutely different meanings), and that character education and virtue education are not the same ( $M=5.32$ ) (Table 2, items 3 and 5). These differences were even more marked in parents' mind ( $M=6.06$ and 5.82, respectively), but pupils were the group who sees less difference between those concepts $(\mathrm{M}=5.09$ and 4.87, respectively). These results were triangulated with respondents' open answers (Table 3). It was found that, overall, more than $2 / 3$ of respondents $(n=493 ; 70.4 \%)$ believed that 'character education' and 'virtue education' are not the same, and only $12.1 \%(\mathrm{n}=85)$ believed that they are the same or similar notions. This general disagreement with international understandings of character and virtue education as being equivalent notions, as reported in the introduction, seems relevant, and it will be addressed in the discussion. However, similarly to the common opinion in virtue ethics, respondents tended to believe that 'virtue' is not only a religious notion ( $M=5.81$, where7 = absolutely not only religious) (Table 2, item 4).

Another relevant finding of this study was that, as the Kruskal-Wallis H Test showed (Table 2), there were statistically significant differences in all the research items' scores of this section between respondent groups. This diversity of understandings as well as the quite high standard deviations found within each group (around 1.5 in a 7-point scale) will also be addressed in the discussion.

Table 2

\section{Respondents' understanding of 'character', 'virtue', 'character education' and 'virtue education'}

\begin{tabular}{|c|c|c|c|c|c|c|c|}
\hline \multirow[t]{2}{*}{ The research items } & $\begin{array}{c}\text { Total } \\
(\mathrm{N}=759)\end{array}$ & $\begin{array}{l}\text { Pupils } \\
(n=226)\end{array}$ & $\begin{array}{l}\text { Students } \\
(n=155)\end{array}$ & $\begin{array}{l}\text { Teachers } \\
(n=116)\end{array}$ & $\begin{array}{l}\text { Leaders } \\
(n=55)\end{array}$ & $\begin{array}{l}\text { Parents } \\
(n=191)\end{array}$ & \multirow{2}{*}{$\begin{array}{l}\text { Kruskal- } \\
\text { Wallis H } \\
\text { Test }\end{array}$} \\
\hline & $\mathrm{M}(\mathrm{SD})$ & $\mathrm{M}(\mathrm{SD})$ & $\mathrm{M}(\mathrm{SD})$ & $\mathrm{M}(\mathrm{SD})$ & $\mathrm{M}(\mathrm{SD})$ & M (SD) & \\
\hline $\begin{array}{l}\text { 1. For me, it's clear what the } \\
\text { notion 'character' means }\end{array}$ & $\begin{array}{c}5.33 \\
(1.57)\end{array}$ & $\begin{array}{c}4.77 \\
(1.59)\end{array}$ & $\begin{array}{c}5.32 \\
(1.14)\end{array}$ & $\begin{array}{c}5.69 \\
(1.53)\end{array}$ & $\begin{array}{c}5.98 \\
(1.45)\end{array}$ & $\begin{array}{c}5.55 \\
(1.70)\end{array}$ & $66.46 * *$ \\
\hline $\begin{array}{l}\text { 2. For me, it's clear what } \\
\text { the notion 'virtue' means }\end{array}$ & $\begin{array}{l}5.85 \\
(1.52)\end{array}$ & $\begin{array}{c}5.73 \\
(1.69)\end{array}$ & $\begin{array}{l}5.65 \\
(1.09)\end{array}$ & $\begin{array}{c}6.01 \\
(1.57)\end{array}$ & $\begin{array}{c}6.05 \\
(1.53)\end{array}$ & $\begin{array}{c}5.99 \\
(1.57)\end{array}$ & $34.04 * *$ \\
\hline $\begin{array}{l}\text { 3. Both the notions } \\
\text { (character and virtue) have } \\
\text { not the same meanings }\end{array}$ & $\begin{array}{c}5.53 \\
(1.67)\end{array}$ & $\begin{array}{l}5.09 \\
(1.67)\end{array}$ & $\begin{array}{c}5.59 \\
(1.43)\end{array}$ & $\begin{array}{l}5.40 \\
(1.93)\end{array}$ & $\begin{array}{c}5.53 \\
(1.83)\end{array}$ & $\begin{array}{c}6.06 \\
(1.53)\end{array}$ & $49.94 * *$ \\
\hline $\begin{array}{l}\text { 4. Virtue is not only a } \\
\text { religious notion }\end{array}$ & $\begin{array}{c}5.81 \\
(1.52)\end{array}$ & $\begin{array}{c}5.22 \\
(1.63)\end{array}$ & $\begin{array}{c}5.88 \\
(1.23)\end{array}$ & $\begin{array}{c}6.12 \\
(1.51)\end{array}$ & $\begin{array}{c}6.35 \\
(1.28)\end{array}$ & $\begin{array}{c}6.10 \\
(1.49)\end{array}$ & $71.66 * *$ \\
\hline $\begin{array}{l}\text { 5. Character education and } \\
\text { virtue education are not the } \\
\text { same }\end{array}$ & $\begin{array}{c}5.32 \\
(1.73)\end{array}$ & $\begin{array}{c}4.87 \\
(1.76)\end{array}$ & $\begin{array}{c}5.43 \\
(1.45)\end{array}$ & $\begin{array}{c}5.27 \\
(1.89)\end{array}$ & $\begin{array}{c}5.11 \\
(2.02)\end{array}$ & $\begin{array}{c}5.82 \\
(1.65)\end{array}$ & $39.94 * *$ \\
\hline
\end{tabular}

$* * \mathrm{p}<0.001 ; * \mathrm{p}<0.05$

Table 3

Respondents' understanding of the differences between 'character education' and 'virtue education'

\begin{tabular}{|l|c|c|c|c|c|c|}
\hline \multicolumn{1}{|c|}{ The research items } & $\begin{array}{c}\text { Total } \\
(\mathbf{N = 6 8 5})\end{array}$ & $\begin{array}{c}\text { Pupils } \\
(\mathbf{n = 2 2 2})\end{array}$ & $\begin{array}{c}\text { Students } \\
(\mathbf{n = 1 1 0})\end{array}$ & $\begin{array}{c}\text { Teachers } \\
(\mathbf{n = 1 1 0})\end{array}$ & $\begin{array}{c}\text { Leaders } \\
(\mathbf{n = 5 3})\end{array}$ & $\begin{array}{c}\text { Parents } \\
(\mathbf{n = 1 9 0})\end{array}$ \\
\cline { 2 - 7 } & $\mathrm{N}(\%)$ & $\mathrm{n}(\%)$ & $\mathrm{n}(\%)$ & $\mathrm{n}(\%)$ & $\mathrm{n}(\%)$ & $\mathrm{n}(\%)$ \\
\hline 1. Character education and virtue & 85 & 43 & 2 & 15 & 8 & 17 \\
education are the same or similar notions & $(12.1 \%)$ & $(19.4 \%)$ & $(1.8 \%)$ & $(13.6 \%)$ & $(15.1 \%)$ & $(8.9 \%)$ \\
\hline $\begin{array}{l}\text { 2. Character education and virtue } \\
\text { education are not the same }\end{array}$ & 493 & 139 & 90 & 80 & 31 & 145 \\
& $(70.4 \%)$ & $(62.6 \%)$ & $(81.8 \%)$ & $(72.7 \%)$ & $(58.5 \%)$ & $(76.3 \%)$ \\
\hline 3. These two notions are interconnected & 44 & 7 & 6 & 8 & 12 & 10 \\
& $(6.3 \%)$ & $(3.2 \%)$ & $(5.5 \%)$ & $7.3 \%)$ & $(22.6 \%)$ & $(5.3 \%)$ \\
\hline 4. Lack of understanding & 60 & 27 & 7 & 6 & 2 & 17 \\
& $(8.6 \%)$ & $(12.2 \%)$ & $(6.4 \%)$ & $(5.5 \%)$ & $(3.8 \%)$ & $(8.9 \%)$ \\
\hline 5. No answer & 18 & 6 & 5 & 1 & - & 1 \\
& $(2.6 \%)$ & $(2.7 \%)$ & $(4.5 \%)$ & $(0.9 \%)$ & & $(0.5 \%)$ \\
\hline
\end{tabular}


As regards the $3^{\text {rd }}$ research question (Agreement/disagreement with myths and misunderstandings about character and virtue education), another relevant finding of this study was that, in general, respondents agreed with statements opposing the myths and misunderstandings about both character education and virtue education presented to them (Table 4). The implications of this finding will be also discussed later.

Table 4

Differences in understanding of 'character education' and 'virtue education' (by respondent group)

\begin{tabular}{|c|c|c|c|c|c|c|c|c|}
\hline \multirow{2}{*}{$\begin{array}{c}\text { Given statements } \\
\quad \text { (anti-myths) } \\
7=\text { absolutely agree }\end{array}$} & $\begin{array}{l}\text { Character } \\
\text { education }\end{array}$ & $\begin{array}{c}\text { Virtue } \\
\text { education }\end{array}$ & $\begin{array}{c}\text { Total } \\
(\mathbf{N}=759)\end{array}$ & $\begin{array}{c}\text { Pupils } \\
(\mathbf{n}=\mathbf{2 2 6})\end{array}$ & $\begin{array}{c}\text { Students } \\
(\mathrm{n}=155)\end{array}$ & $\begin{array}{c}\text { Teachers } \\
(n=116)\end{array}$ & $\begin{array}{c}\text { Leaders } \\
(\mathbf{n}=55)\end{array}$ & $\begin{array}{l}\text { Parents } \\
(\mathrm{n}=191)\end{array}$ \\
\hline & $\mathrm{M}(\mathrm{SD})$ & $\mathrm{M}(\mathrm{SD})$ & $\mathrm{Z}$ & $\mathrm{Z}$ & $\mathrm{Z}$ & $\mathrm{Z}$ & $\mathrm{Z}$ & $\mathrm{Z}$ \\
\hline $\begin{array}{l}\text { 1. Promotes a critical } \\
\text { thinking }\end{array}$ & $\begin{array}{c}5.36 \\
(1.54)\end{array}$ & $\begin{array}{c}4.74 \\
(1.71)\end{array}$ & $-8.38 * *$ & $-5.34 * *$ & $-5.51 * *$ & $-2.89 *$ & -0.45 & $-2.99 *$ \\
\hline $\begin{array}{l}\text { 2. Promotes a personal } \\
\text { freedom }\end{array}$ & $\begin{array}{c}5.37 \\
(1.56)\end{array}$ & $\begin{array}{c}4.65 \\
(1.69)\end{array}$ & $-9.54 * *$ & $-5.89 * *$ & $-4.19 * *$ & $-3.34 *$ & -0.29 & $-4.78 * *$ \\
\hline $\begin{array}{l}\text { 3. Not related to a } \\
\text { religious doctrine }\end{array}$ & $\begin{array}{c}5.61 \\
(1.55)\end{array}$ & $\begin{array}{c}4.60 \\
(1.88) \\
\end{array}$ & $-13.03 * *$ & $-7.27 * *$ & $-6.33 * *$ & $-4.81 * *$ & -0.04 & $-7.67 * *$ \\
\hline $\begin{array}{l}\text { 4. Not related to political } \\
\text { orientation }\end{array}$ & $\begin{array}{c}5.55 \\
(1.61) \\
\end{array}$ & $\begin{array}{c}5.09 \\
(1.75) \\
\end{array}$ & $-7.79 * *$ & $-5.68 * *$ & $-2.46^{*}$ & $-3.45^{*}$ & -1.50 & $-3.89 * *$ \\
\hline $\begin{array}{l}\text { 5. Improves an academic } \\
\text { performance of students }\end{array}$ & $\begin{array}{c}5.43 \\
(1.54)\end{array}$ & $\begin{array}{c}4.54 \\
(1.63)\end{array}$ & $-11.99 * *$ & $-5.56 * *$ & $-5.25 * *$ & $-4.34 * *$ & $-2.59 *$ & $-7.48 * *$ \\
\hline $\begin{array}{l}\text { 6. Improves the behaviour } \\
\text { of students }\end{array}$ & $\begin{array}{c}5.68 \\
(1.47)\end{array}$ & $\begin{array}{c}5.53 \\
(1.42)\end{array}$ & $-2.53 *$ & $-4.08 * *$ & -0.65 & -0.42 & -1.19 & -1.05 \\
\hline $\begin{array}{l}\text { 7. Enhances the } \\
\text { employment opportunities }\end{array}$ & $\begin{array}{c}5.48 \\
(1.45) \\
\end{array}$ & $\begin{array}{c}4.63 \\
(1.62) \\
\end{array}$ & $-12.97 * *$ & $-7.27 * *$ & $-5.88 * *$ & $-4.35 * *$ & $-3.68 * *$ & $-6.51 * *$ \\
\hline $\begin{array}{l}8 . \text { Helps to build good } \\
\text { relationships }\end{array}$ & $\begin{array}{c}5.42 \\
(1.59)\end{array}$ & $\begin{array}{l}5.25 \\
(1.64)\end{array}$ & $2.85 *$ & $-4.05 * *$ & -0.62 & -1.19 & -1.18 & -0.41 \\
\hline $\begin{array}{l}\text { 9. Encourages belonging } \\
\text { to a democratic society }\end{array}$ & $\begin{array}{c}4.64 \\
(1.61)\end{array}$ & $\begin{array}{c}4.57 \\
(1.65)\end{array}$ & -0.92 & $-2.04 *$ & $-2.05^{*}$ & -1.13 & -1.91 & $-2.51 *$ \\
\hline $\begin{array}{l}\text { 10. Promotes individual } \\
\text { and social well-being }\end{array}$ & $\begin{array}{c}5.11 \\
(1.66) \\
\end{array}$ & $\begin{array}{c}5.19 \\
(1.55) \\
\end{array}$ & -1.15 & -1.56 & $-2.94 *$ & -1.29 & -1.72 & -0.22 \\
\hline
\end{tabular}

**p $<0.001, * \mathrm{p}<0.05, \mathrm{Z}$ - Wilcoxon Signed-Rank Test

In addition, in most of the criteria, the disagreement with those myths was stronger when applied to 'character education' than to 'virtue education'. This finding (that character education and virtue education are different) echoes the finding reported previously. For example, 'character education' is believed to promote better critical thinking and personal freedom, to have a bigger impact on students' academic performance and behaviour, to be less related to a specific religious doctrine or political orientation, and to help better to build good relationships and to find a job. On the other side, respondents believed that virtue education promotes both individual and social well-being better than character education $(\mathrm{M}=5.19$ and 5.11, respectively). The indicator which received the strongest agreement relating both to character education and virtue education was their impact on improving students' behaviour ( $\mathrm{M}=5.68$ and 5.53, respectively); the indicator related to the impact of character education on 'belonging to a democratic society' received the weakest agreement $(\mathrm{M}=4.64)$; and the indicator related to virtue education impact on students' academic performance received the weakest agreement $(\mathrm{M}=4.54)$.

Those differences between character education and virtue education were perceived by all the five respondent groups, but the difference is less often statistically significant in the case of school leading staff, and more often statistically significant in the case of pupils.

Regarding in-service teachers' $(n=116)$ and school leading staff $(n=55)$ agreement with the different definitions of character education presented to them (Table 5), overall, they mostly agree with all the definitions and there were no differences among those two respondent groups. A comparison of frequencies was performed merging both respondent groups.

In the assessment of the definitions, in-service teachers and school leading staff were tended to give affirmative answers, in general more likely agreeing to definitions with focus on learning or rather neutrally perceiving the proposed definitions with focus on teaching. The two definitions which got the highest perceptual agreement (Table 5, items 6 and 7) had a focus on pupils' learning (the youngsters themselves 
develop their virtues) and included non-formal education elements, such as long-term processes and implicit education. On the other side, the two definitions which got the highest level of neutral attitude (Table 5, items 3 and 5) referred to explicit teaching and formal education settings.

Table 5

Frequencies (\%) of agreement with definitions of character education (teachers and school leaders)

\begin{tabular}{|l|c|c|c|c|}
\hline \multicolumn{1}{|c|}{ Proposed definitions of character education } & Focus* & Disagree & Neutral & Agree \\
\hline $\begin{array}{l}\text { 1. Character education is } \text { a method of internal discipline and motivation for } \\
\text { students (Krolis, 2017). }\end{array}$ & (L, F) & 12.8 & 36.0 & $\mathbf{5 1 . 2}$ \\
\hline $\begin{array}{l}\text { 2. Character education implies a more deliberate approach - a conscious } \\
\text { decision to develop certain students' virtues, behaviours and attitudes and a } \\
\text { plan as to how this will be achieved (What is Character..., 2019). }\end{array}$ & (T, F) & 12.2 & 37.2 & $\mathbf{5 0 . 6}$ \\
\hline $\begin{array}{l}\text { 3. Character education is any form of moral education that foregrounds the } \\
\text { role of virtuous character in the good life (Kristjánsson, 2013). }\end{array}$ & $\begin{array}{c}\text { (T, F, } \\
\text { NF) }\end{array}$ & 11.6 & $\mathbf{5 3 . 7}$ & 34.8 \\
\hline $\begin{array}{l}\text { 4. Character education is a learning process that enables students and adults } \\
\text { in a school community to understand, care about and act on core ethical } \\
\text { values such as respect, justice, civic virtue and citizenship, and } \\
\text { responsibility for self and others (Character Education..., 2005). }\end{array}$ & 11.6 & 41.5 & $\mathbf{4 7 . 0}$ \\
\hline $\begin{array}{l}\text { 5. Character education is the intentional effort to develop in young people } \\
\text { core ethical and performance values that are widely affirmed across all } \\
\text { cultures (Eleven Principles of..., 2010). }\end{array}$ & (T, F) & 11.0 & $\mathbf{4 9 . 4}$ & 39.6 \\
\hline $\begin{array}{l}\text { 6. Character education is the long-term process of helping young people to } \\
\text { develop a good character, i.e., knowing, caring about, and acting upon core } \\
\text { ethical values (Berkowitz, 2008). }\end{array}$ & $\begin{array}{c}\text { (L, } \\
\text { NF) }\end{array}$ & 16.5 & 23.8 & $\mathbf{5 9 . 8}$ \\
\hline $\begin{array}{l}\text { 7. Character education is the explicit and implicit educational activities that } \\
\text { help young people to develop virtues (Harrison, Morris, Ryan, 2016; The } \\
\text { Jubilee Centre..., 2017). }\end{array}$ & $\begin{array}{c}\text { (T, L, } \\
\text { F, }\end{array}$ & 14.0 & 32.9 & $\mathbf{5 3 . 0}$ \\
\hline
\end{tabular}

$* T=$ focus on teaching; $L=$ focus on learning; $F=$ focus on formal education; $N F=$ focus on non-formal education

\section{Discussion}

Character education and virtue education seem to be perceived as two different constructs in Riga. A possible explanation could be that, during the Soviet times, the term character was understood in a very specific, narrow way. Since the beginning of the Soviet times, at the beginning of the 20th century, the Soviet system put at the centre of the education policy a number of so called "Soviet virtues", such as 'Soviet patriotism', 'social humanism' and 'collectivism', while the term 'character education' was reserved to the development of the discipline and will strength expected from the New Soviet Man (Fernández-González, 2019d). This distinction between character education (in a narrow sense) and virtue education might be still present in Latvia, which was under the Soviet rule for more than 50 years.

In spite of the subjective self-perceived clarity of the concepts of character and virtue reported by respondents, the data revealed a rich diversity of understandings of those concepts between the different groups and within groups. It seems that there is not a common understanding of these terms in Latvian educational system, at least in Riga. This fact could explain the contradictory debates originated in Latvian media during the legislative process leading to the approval of the Guidelines for moral education, as explained in the introduction. It could be advanced that working on the creation of a common understanding of the main terms could be beneficial for the whole educational system, facilitating the acknowledgement of the benefits of character and virtue education at school, and increasing its acceptance in Latvian society. Most of respondents did not take for granted some of the myths and misunderstandings about character education presented to them. This seems to indicate that, in Riga, there is a general a positive opinion and acceptance of 'virtue education', and, even more, of 'character education': they are often seen as complementary and working in synergy.

Finally, it should be noted that the results of this study refer to Riga city. Considering its importance in Latvia, it is possible that they reflect the situation in Latvia, but more research is needed to verify this hypothesis. 


\section{Conclusions}

In Riga educational system, there is a general agreement of all respondent groups (parents, pupils, preservice and in-service teachers as well as school leading staff) that character and virtue are quite well-known but different terms; therefore, character education and virtue education are also different concepts, but they are interconnected. Respondents have a quite positive opinion and acceptance of both character education and virtue education, and this tendency is stronger regarding character education. Both kinds of education are particularly relevant to improve students' behaviour. Respondents particularly strongly agree that character education is not directly related to religious or political education, and that it enhances academic performance and employability, whereas virtue education is particularly helpful to build good relationships and promotes both individual and social well-being. In-service teachers and school leading staff reported the highest agreement to definitions of character education that included both pupils' self-involvement and non-formal education activities.

A deeper understanding of the benefits of character education in Latvia might be facilitated within the institutional efforts of elaboration and implementation of character education programmes at school (a good practice example in Riga Catholic Gymnasium). Research projects, where practitioners, policy makers and researchers share their understandings and join their efforts for having an impact on society, are also relevant. Many efforts are being done in this field in Latvia, e.g.: the Erasmus+ project "Shaping Characters" (2015-2017); the University of Latvia's research project "Teachers' ethics, development of transversal and socio-emotional competences and character education to promote quality of education" (2016-2019); the Erasmus ${ }^{+}$project "Arete Catalyst" (2017-2019); the postdoctoral research project "Modernization of school education in Latvia through an innovative research-based program on 21st century competences and virtue ethics development supported by a virtual campus (ARETE-school)" (2017-2020), as well as many other initiatives implemented in Latvia.

Given the differences in the understanding of the concepts of character and virtue across and within different respondent groups, it would be beneficial to work on building a common understanding of these notions which is attuned with the main stream international literature on virtue ethics. This would probably facilitate setting up joint international research projects and sharing educational materials about character and virtue education across different countries.

\section{Acknowledgements}

Research financed by the European Regional Development Fund within the post-doctoral project "Arete school", project number 1.1.1.2/VIAA/1/16/071, and by the University of Latvia within the research project "Human, technologies and quality of education" (2016-2019) conducted at the Faculty of Education, Psychology and Art.

\section{Bibliography}

1. Berkowitz M.W. (2008). A Primer for Evaluating a Character Education Initiative (2 ${ }^{\text {nd }}$ ed.). Washington: Character Education Partnership.

2. Berkowitz M.W., Bier M.C. (2006). What works in character education: A research-driven guide for educators. Washington: Center for Character and Citizenship. Retrieved from https://www.researchgate.net/publication/251977043_What_Works_In_Character_Education

3. Character Education... Our Shared Responsibility. (2005). Washington: U.S. Department of Education, Office of Safe and Drug-Free Schools. Retrieved from https://www2.ed.gov/admins/lead/character/brochure.html

4. 'Courage' and 'Moderation' Join Upbringing Guidelines. (2016). Latvian Public Broadcasting (eng.lsm.lv). Retrieved from https://eng.lsm.lv/article/society/society/courage-and-moderation-joinupbringing-guidelines.a167479/

5. Eleven Principles of Effective Character Education: A Framework for School Success. (2010). Washington: Character Education Partnership. Retrieved from https://coreessentials.org/assets/uploads/content/ce-11-principles.pdf

6. Fernández-González M.J. (2018). Zinātniski pētniecisks skatījums uz rakstura audzināšanu: mīti, izaicinājumi un starptautiskās perspektīvas [Research-Based Reflections about Character Education: Myths, Challenges and International Perspectives]. In V. Lubkina, S. Usca, A. Zvaigzne (Eds.), The Proceedings of the International Scientific Conference Society. Integration. Education, 2. Rezekne: RTA, 126-136. doi: 10.17770/sie2018vol1.3133 (in Latvian) 
7. Fernández-González M.J. (2019a). Cultural and Historical Research on Character and Virtue Education in Latvia in an International Perspective. Research Report. Retrieved from https://drive.google.com/file/d/1X15P6ubTIfWTKshOnYIpQoMdCJCso5rB/view

8. Fernández-González M.J. (2019b). Skolēnu morālā audzināšana Latvijas skolās: vecāku, skolotāju, topošo skolotāju un skolu un izglītības pārvalžu vadītāju viedokl̦i. Populārzinātniskais pētījuma ziņojums [Moral Education of Pupils in Latvian Schools: The Views of Parents, Teachers, Future Teachers, Heads of Schools and Education Boards. Popular Science Research Report]. Rīga: LU PPMF Pedagoǵijas zinātniskais institūts. Retrieved from http://dspace.lu.lv/dspace/bitstream/handle/7/46498/Zi\%20ojums_Skol\%20nu\%20mor\%201\%20\%20audzin \%20\%20ana\%20Latvijas\%20skol\%20s.pdf (in Latvian)

9. Fernández-González M.J. (2019c). Par tikumiskās audzināšanas jēdzienu izpratni [About an Understanding of the Concepts of Virtue Education]. Domāt. Darīt. Zināt., 9, 16-19. Retrieved from http://skola2030.lv/admin/filemanager/files/2/nr_9.pdf (in Latvian)

10. Fernández-González M.J. (2019d). Legitimation of Virtue Education in Teacher Training Discourse during Soviet Latvia. In V. Lubkina, A. Indriksons, S. Usca (Eds.), The Proceedings of the International Scientific Conference Society. Integration. Education, 1. Rezekne: RTA, 194-204. doi: 10.17770/sie2019vol1.3916

11. Goodman F.R., Disabato D.J., Kashdan T.B. (2019). Integrating Psychological Strengths under the Umbrella of Personality Science: Rethinking the Definition, Measurement, and Modification of Strengths. The Journal of Positive Psychology, 14(1), 61-67. doi: 10.1080/17439760.2018.1528380

12. Harrison T., Morris I., Ryan J. (2016). Teaching Character in Primary Schools. London: Sage.

13. Izglītojamo audzināšanas vadlīnijas un informācijas, māā̄bu līdzekl̦u, materiālu un mācību un audzināšanas metožu izvērtēšanas kārtība [Guidelines for the Upbringing of Learners and the Procedure for Evaluating Information, Teaching Aids, Materials and Teaching/Learning and Upbringing Methods]. (2016). Retrieved from https://likumi.lv/ta/id/283735 (in Latvian)

14. Kristjánsson K. (2013). Ten Myths about Character, Virtue and Virtue Education - Plus Three WellFounded Misgivings. British Journal of Educational Studies, 61(3), 269-287. doi: 10.1080/00071005.2013.778386

15. Krolis L. (2017). Raksturizglītība mudina tiekties uz labo. Rīgas Katoḷu gimnāzijas pieredze [Character Education Encourages the Pursuit of Good. Experience of Riga Catholic Gymnasium]. Retrieved from https://tuvuma.lv/raksturizglitiba-mudina-tiekties-uz-labo-rigas-katolu-gimnazijas-pieredze (in Latvian)

16. McCullough M.E., Snyder C.R. (2000). Classical Sources of Human Strength: Revisiting an Old Home and Building a New One. Journal of Social and Clinical Psychology, 19(1), 1-10. doi: $10.1521 /$ jscp.2000.19.1.1

17. Morality Guidelines Workgroup Discusses Nine Virtues. (2015). Latvian Public Broadcasting (eng.lsm.lv). Retrieved from https://eng.lsm.lv/article/society/society/morality-guidelineswork-group-discusses-nine-virtues.a159698/

18. Park N., Peterson C., Seligman M.E.P. (2004). Strengths of Character and Well-being. Journal of Social and Clinical Psychology, 23(5), 603-619. doi: 10.1521/jscp.23.5.603.50748

19. Peterson C., Seligman M.E.P. (2004). Character Strengths and Virtues: A Handbook and Classification. New York: Oxford University Press. Retrieved from http://ldysinger.stjohnsem.edu/\%40books1/Peterson_ Character_Strengths/character-strengths-and-virtues.pdf

20. Saeima Approves Lessons in 'Constitutional Morality' for Schoolchildren. (2015). Latvian Public Broadcasting (eng.lsm.lv). Retrieved from https://eng.lsm.lv/article/society/society/saeima-approveslessons-in-constitutional-morality-for-schoolchildren.a134466/

21. Surikova S., Pigozne T. (2018). Transversal Competences and Character Education in Latvia: A Needs Analysis Report. Retrieved from https://dspace.lu.lv/dspace/handle/7/49011

22. The Jubilee Centre for Character and Virtues. (2017). Framework for Character Education in Schools. Birmingham: University of Birmingham. Retrieved from http://jubileecentre.ac.uk/userfiles/jubileecentre/pdf/other-centre-papers/Framework.pdf

23. The National Society. (2017). Leadership of Character Education: Developing Virtues and Celebrating Human Flourishing in Schools. Retrieved from https://cofefoundation.contentfiles.net/media/assets/file/CEFEL_LeadershipCharacter_Report_WEB.pdf

24. What is Character Education? (2019). Factsheet 1. Shaping Characters. Retrieved from http://www.shapingcharacters.eu/wp-content/uploads/Factsheet-1-Screen-EN.pdf 